\title{
PAX5 Negative
}

National Cancer Institute

\section{Source}

National Cancer Institute. PAX5 Negative. NCI Thesaurus. Code C162078.

An indication that PAX5 expression has not been detected in a sample. 